DOI: $10.15593 / 2224-9354 / 2019.3 .12$

УДК 338.43 .02

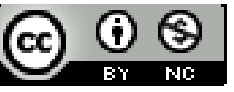

\title{
3.Б. Алиева
}

\section{ПРОБЛЕМЫ И ТЕНДЕНЦИИ ГОСУДАРСТВЕННОЙ АГРАРНОЙ ПОЛИТИКИ В СВЕТЕ ФЕДЕРАЛЬНОГО ПРОЕКТА «ЭКСПОРТ ПРОДУКЦИИ АПК»}

\begin{abstract}
Проведен анализ влияния финансово-кредитных инструментов на внешнеэкономическую деятельность в разрезе экспорта и импорта РФ продовольственных товаров и сельскохозяйственного сырья в период 2000-2017 гг. Раскрыты основные направления федерального проекта «Экспорт продукции АПК», в том числе комплексная программа международной конкурентоспособности (КПМК), вопросы внедрения инновационных технологий при производстве органической продукции, эксплуатации залежных земель в России. С целью определения оптимальных объемов льготного кредитования, повышения производительности труда, полной загрузки имеющихся производственных мощностей и, как следствие, увеличения рентабельности завода произведен расчет максимально возможных объемов производства виноматериалов, натуральных и шампанских вин на ОАО «Дербентский завод игристых вин» («ДЗИВ»). В расчетах были использованы экономико-математические методы в виде линейных уравнений. Исходя из данных Организации экономического сотрудничества и развития (ОЭСР) исследованы корреляционные (взаимосвязанные) проблемы, влияющие на низкие результаты производительности труда в России и затрудняющие процесс «прорывного» развития АПК, вследствие чего обозначены пять основных причин снижения производительности труда в отрасли. С целью выявления критериев потенциального роста производительности труда автором произведен сравнительный анализ показателя индекса производительности труда в сельском хозяйстве и основным отраслям экономики РФ в 2003-2014 гг. (в \% к предыдущему году). В условиях пролонгации санкций США и стран Евросоюза в отношении России, продолжающейся политики импортозамещения, автором акцентировано внимание на изучении «прорывных» методов внедрения инновационных технологий и проектов в аграрный сектор народного хозяйства.

Ключевые слова: импорт и экспорт продовольственных товаров и сельскохозяйственного сырья, биологизация, производительность труда, инновационные технологии, государственное регулирование АПК, льготный кредит.
\end{abstract}

Анализ внешнеэкономической деятельности в разрезе импортноэкспортных отношений России свидетельствует о резком падении объемов закупок-поставок в период начала действия санкционных мер (с 2014 г.) (рис. 1, 2). Но необходимо отметить, что оказываемая в этот период политика государственной поддержки АПК, в том числе в виде льготного кредитования всех форм хозяйствования на селе, благотворно отразилась на повышенных темпах производства сельскохозяйственной продукции и положительной динамике экспорта продовольственных товаров и сельскохозяйственного сырья в период 2015-2017 гг. (см. рис. 1).

(C) Алиева 3.Б., 2019

Алиева Зарема Багаутдиновна - канд. экон. наук, доцент, доцент кафедры «Финансы и кредит» ГАОУ ВО «Дагестанский государственный университет народного хозяйства», e-mail: aliza69@mail.ru. 


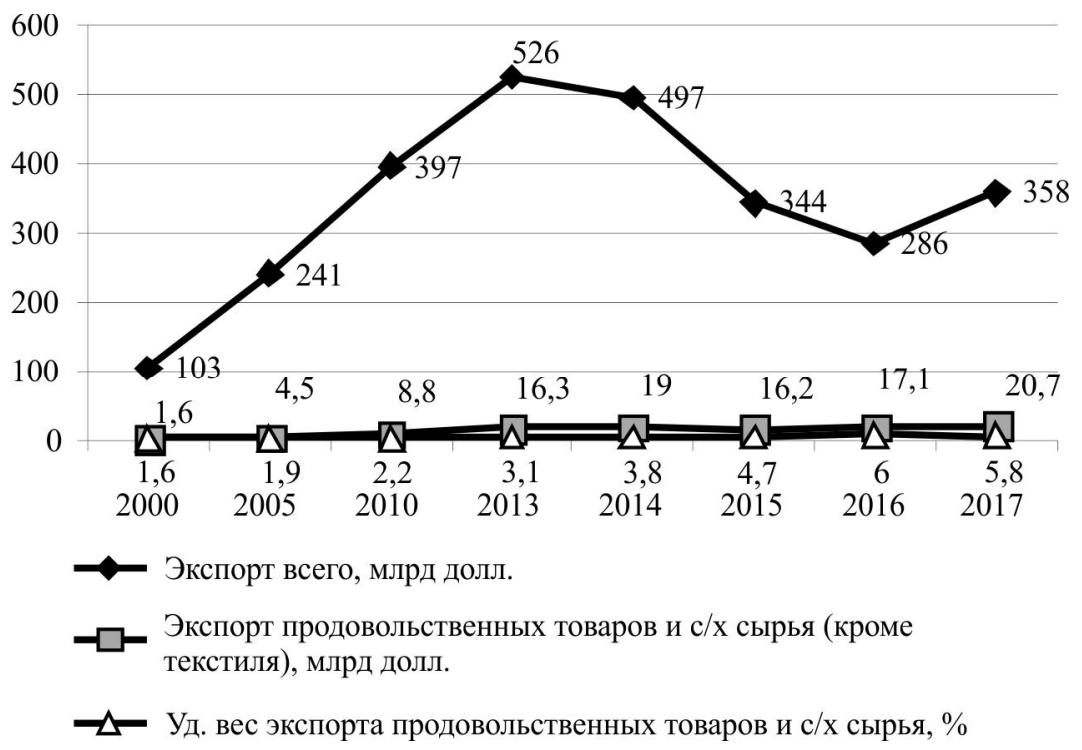

Рис. 1. Динамика экспорта РФ продовольственных товаров и сельскохозяйственного сырья (кроме текстиля) (в фактически действовавших ценах, млрд долл.) [1, с. 493]

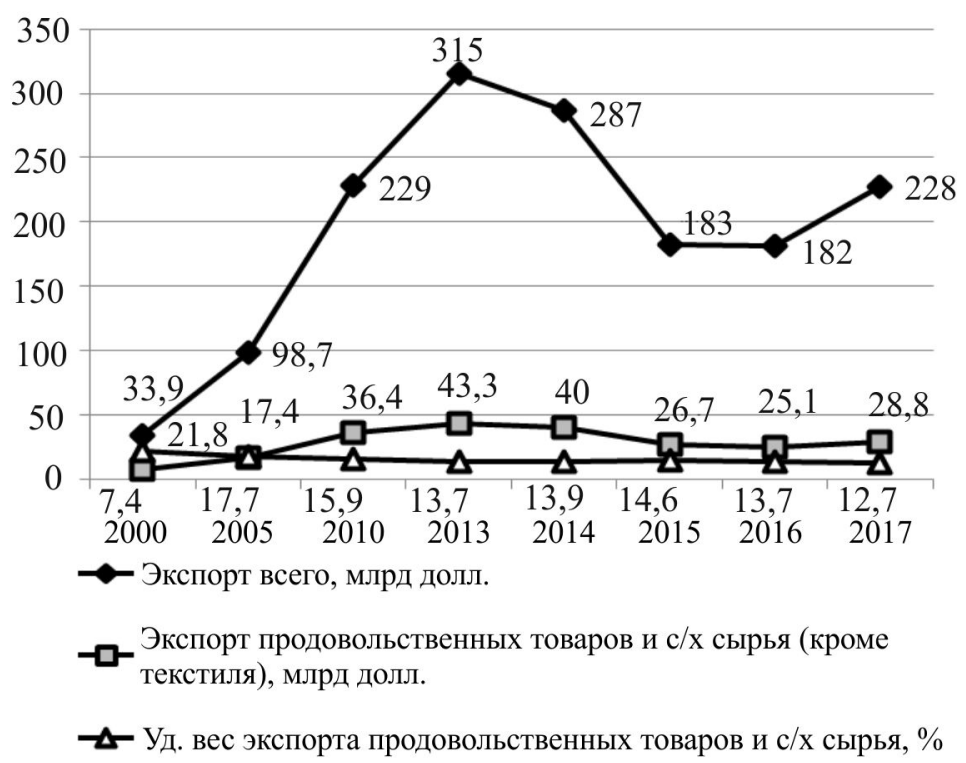

Рис. 2. Динамика импорта РФ продовольственных товаров и сельскохозяйственного сырья (кроме текстиля) (в фактически действовавших ценах, млрд долл.) [1, с. 496] 
Но, как видно, уже в 2017 г. ситуация начала меняться к лучшему: обороты экспортно-импортных операций увеличились как в целом, так и по продовольственным товарам и сельскохозяйственному сырью в частности (см. рис. 1, 2). Проводимая в данный период Россией политика «зеркальных» мер не замедлила отразиться на стабилизации российской экономики и, в том числе увеличении объемов поставок продовольственных товаров и сельскохозяйственного сырья (2015-2017 гг.), а удельный вес экспорта сельхозпродукции в общем объеме экспорта 2014-2016 гг. [2] даже увеличился.

«При этом, по экспертным оценкам, в следующем году (Авm. - 2019 г.) на четверть может вырасти экспорт продукции масложировой отрасли и составить порядка 4 млрд долл. США. Кроме того, существенного роста Минсельхоз ожидает и в части поставок мясной и молочной продукции. В следующем году экспорт по этому направлению может увеличиться на 73 \%, превысив 1,1 млрд долл. США» [3].

Проектный комитет национального проекта «Международная кооперация и экспорт» утвердил паспорт Федерального проекта «Экспорт продукции АПК». На его реализацию до 2024 г. предусмотрено 406,8 млрд руб. Финансирование будет направлено на увеличение объемов производства продукции АПК, построение эффективной аграрно-логистической инфраструктуры, снятие тарифных и нетарифных ограничений на внешних рынках, а также создание системы продвижения и позиционирования отечественной сельскохозяйственной продукции. Для достижения целевого показателя экспорта к 2024 г. в 45 млрд долл. планируется увеличение поставок за рубеж продукции масложировой отрасли, пищевой и перерабатывающей промышленности, рыбы и морепродуктов, зерновых культур, продукции мясной и молочной промышленности, а также других сельскохозяйственных товаров. По каждой из приоритетных подотраслей будут разработаны планы увеличения экспорта и определены ключевые рынки сбыта - Китай, Индия, Япония, страны ЮгоВосточной Азии, Персидского залива, Африки. Одним из ключевых механизмов реализации проекта станет комплексная программа международной конкурентоспособности (КПМК).

Данная программа предусматривает заключение соглашений между государством и бизнесом, направленных на оказание прицельной поддержки экспортоориентированным производствам [4]. В ее рамках производители сельхозпродукции будут получать кредитные средства по льготной ставке на развитие производства взамен на обязательства по наращиванию экспорта продукции АПК [5]. На текущий момент в Минсельхоз России поступило более 400 подобных проектов, которые должны обеспечить прирост экспорта продукции АПК в объеме 17,5 млрд долл. Согласно паспорту национального проекта, осуществление господдержки через механизм КПМК планируется с 2019 по 2021 г. включительно. В общей сложности за указанный период 
планируется заключение не менее 100 соглашений в рамках КПМК по ключевым направлениям [4].

Курс на импортозамещение также благотворно сказался на показателях импорта продовольственных товаров и сельскохозяйственного сырья и удельном весе импорта сельхозпродукции, которые имели устойчивую тенденцию к снижению в течение 2014-2016 гг. (см. рис. 2) и только в 2017 г. в результате некоторой стабилизации отношений со странами ЕС и США показатели импорта увеличились. Но, несмотря на некоторую стабилизацию импортных операций, в России в целом и в том числе по продовольственным товарам и сельскохозяйственному сырью в период 2015-2017 гг. (см. рис. 2) доля импорта сельхозпродукции в общем объеме импорта в этот период уменьшилась на 1,9 \% (с 14,6 \% в 2015 г. до 12,7 \% в 2017 г.).

Одним из направлений актуализации инструментов финансово-кредитной политики в сфере АПК может явиться льготное кредитование ориентированных на экспорт предприятий в рамках региональных целевых программ, например, в Республике Дагестан к таковым можно отнести ОАО «Дербентский завод игристых вин» (ОАО «ДЗИВ»).

Для определения оптимальных объемов льготного кредитования с целью повышения производительности труда, полной загрузки имеющихся производственных мощностей и, как следствие, увеличения рентабельности завода, на наш взгляд, целесообразно произвести расчет максимально возможных объемов производства виноматериалов, натуральных и шампанских вин на ОАО «ДЗИВ». Исходя из этого, применим экономико-математические методы с помощью несложных линейных уравнений.

Согласно основным производственным показателям, ОАО «ДЗИВ» может увеличить производство виноматериалов для производства 2 видов алкогольной продукции: шампанских вин, натуральных вин. В 2016 г. произведено: вина шампанского - 1979,1 тыс. дал, вина натурального - 77,9 тыс. дал. Спрос на эти виды продукции определим в размере имеющихся у ОАО «ДЗИВ» производственных мощностей в 2016 г.: по шампанским винам 5034 тыс. дал, по натуральным винам - 461 тыс. дал в год (таблица).

Динамика основных производственных показателей ОАО «ДЗИВ» [6]

\begin{tabular}{|l|c|c|c|c|c|}
\hline \multicolumn{1}{|c|}{ Наименование показателя } & Ед. изм. & 2013 & 2014 & 2015 & 2016 \\
\hline 1. Переработка винограда & т & 29503 & 28754 & 28254 & 26136 \\
\hline 2. Выработано виноматериала & тыс. дал & 2063,47 & 2063 & 2309,9 & 1828,6 \\
\hline 3. Произведено: & & & & & \\
3.1. вино шампанское & тыс. дал & 2190,3 & 2121,94 & 2249,3 & 1979,1 \\
3.2. вино натуральное [7] & & 35,56 & 39,39 & 65,63 & 77,9 \\
\hline 4. Производственная мощ- & & & & & \\
ность: & тыс. дал & 3900 & 3900 & 5025 & 5034 \\
4.1. шампанское & 418 & 418 & 418 & 461 \\
4.2. вино натуральное & & & & & \\
\hline
\end{tabular}




\section{Необходимо определить:}

1) во сколько раз должно быть увеличено производство шампанского и натурального вина, чтобы полностью загрузить производственные мощности завода;

2) объем виноматериалов, необходимых для полной загрузки производственных мощностей;

3) сколько тонн винограда необходимо переработать для производства необходимого объема виноматериалов.

\section{Алгоритм расчетов:}

1. Пусть $\mathrm{X}$ - объем виноматериалов для производства шампанских вин; $\mathrm{Y}$ - объем виноматериалов для производства натуральных вин. Тогда количество произведенной алкогольной продукции составит:

шампанских вин: $1979,1 \cdot X=5034$ тыс. дал.;

$\mathrm{X}=2$, в 54 раза должен быть увеличен объем виноматериалов для производства шампанских вин;

натуральных вин: 77,9·Y $=461$ тыс. дал.

$\mathrm{Y}=5$, в 91 раз должен быть увеличен объем виноматериалов для производства натуральных вин.

2. Рассчитаем объем виноматериалов, необходимых для полной загрузки производственных мощностей (см. таблицу): (сумма пп. 4.1 и 4.2) - (сумма пп. 3.1 и 3.2): $(5034+461)-(1979,1+77,9)=3438,1$ тыс. дал.

3. Рассчитаем, сколько тонн винограда надо переработать для производства необходимого объема виноматериалов.

Рассчитаем, сколько виноматериалов (в дал) даст переработка 1 т винограда при условии, что весь переработанный виноград идет на производство виноматериалов (п. 2 / п.1, см. таблицу): 1828,6 $: 26136=0,069 \approx 0,07$ дал. Если количество винограда, необходимого для полной загрузки производственных мощностей винзавода и производства виноматериалов, обозначим $\mathrm{X}$, то получим несложное линейное уравнение: $0,07 \cdot \mathrm{X}=3438,1 ; \mathrm{X}=49115,7$ т винограда.

$\mathrm{B}$ век интенсивного развития и внедрения инновационных технологий, роста численности мирового населения, ухудшения качественных характеристик и деградации почв получило популярность производство продукции, содержащей ГМО. Существует множество точек зрения и сторонников производства продукции, содержащей ГМО, и экологически чистой органической продукции. В подходе к решению данного вопроса нам импонирует точка зрения Е. Савченко, губернатора Белгородской области. По его мнению, «ключевыми параметрами нацпроекта по восстановлению села должны стать восстановление почв, господдержка семейных ферм и большие кредиты селянам». Согласно Ф3 «О производстве органической продукции» от 2018 г. можно выйти на решение других, крайне актуальных проблем в целом в сельском хозяйстве и в сельских территориях. Без почв нельзя вести разго- 
вор о производстве органической продукции. Привести их в порядок можно только через большой проект и федеральный закон о биологизации земледелия (одноименная программа была принята в Белгородской области восемь лет назад). «За эти годы на каждый гектар пашни возвращается 6 т органического вещества в сухом виде. А вынос с урожаем составляет в среднем 5 т с гектара. Поэтому мы обеспечиваем профицитный баланс гумуса. За эти годы, по нашим данным, содержание гумуса прекратило сокращаться, а наоборот, увеличивается. Есть поля и площадки, на которых рост содержания гумуса составляет от 0,1 до 0,3 \%. Как результат - урожайность повысилась в 1,5-2 раза, а прибыль с 1 га превышает 10 тыс. руб.» [8].

На сегодняшний день продолжает оставаться острой проблемой вопрос эксплуатации залежных земель в России, которые не обрабатывались более 25 лет. Их насчитывается около 5 млн га. В решении этого важного народнохозяйственного вопроса должна помочь поддержка со стороны государства в отношении малых форм хозяйствования, и прежде всего семейных ферм. Необходимо запустить программу кредитования селян на сумму до 10 млн руб. на постройку и обустройство дома. При этом при рождении в семье детей часть долга должна списываться автоматически. Так, можно начать решать сразу две проблемы: во-первых, демографическую проблему в России и, вовторых, проблему эксплуатации залежных земель. А для этого необходимо отказаться от поддержки крупных агрохолдингов, которые получают 80 \% финансовой поддержки на сельское хозяйство со стороны государства.

В настоящее время целесообразнее оказывать господдержку агрохолдингов в софинансировании крупных научных исследований. Они ведь не платят подоходный налог. Если 50 \% этой суммы направить на инновации и столько же получить со стороны государства, представляете, какой огромный ресурс мог бы быть направлен на развитие научных исследований, НИОКР. И, естественно, в первую очередь в этом были бы задействованы подразделения РАН.

Таким образом, можно было бы создать новый экономический уклад на селе: рекреационное сельское хозяйство, которое станет не альтернативой крупному индустриальному производству, а существенным дополнением и главным производителем органической и экологически чистой продукции [8].

В качестве одного из путей активизации инновационных процессов в АПК, на наш взгляд, необходим трансферт современных технологий в аграрное производство малых форм хозяйствования. Как свидетельствует мировой опыт, инновационное развитие растениеводства основывается на применении ресурсосберегающих технологий и современной техники, в том числе робототехники с высоким коэффициентом полезного действия. Если сравнить российские сельскохозяйственные предприятия с аналогичными предприятиями в странах ЕС и США по показателю энергообеспеченности на 
100 га посевной площади, то статистические данные свидетельствуют об очень низком их уровне: в 4 раза ниже, чем в ЕС и в 6 раз ниже, чем в США. Более половины всей техники, применяемой в АПК, давно выработало срок эксплуатации и нуждается в срочной замене. А современная высокопроизводительная сельскохозяйственная техника позволяет сэкономить на 3-4 работниках сельского хозяйства, что логично скажется на сокращении неэффективных затрат труда и своевременности проведения сельскохозяйственных работ. Согласно исследованиям, сокращение сроков уборки зерна позволяет сократить потери на 6-18\% $[9$, с. 31].

В последние годы, благодаря целенаправленной государственной политике, уверенно растет аграрное производство. Для реализации задачи по увеличению экспорта сельхозпродукции к 2024 г. в России будет создана широкая сеть атташе по АПК, деятельность которых будет способствовать сокращению издержек сельхозпроизводителей для выхода на новые рынки, увеличению конкурентоспособности отечественной продукции за рубежом и расширению видов экспортной продукции. «Это в том числе позволит России в среднесрочной перспективе войти в десятку крупнейших мировых экспортеров сельхозпродукции, а по отдельным позициям - занять место в тройке лидеров: например, зерно и продукция масложировой отрасли» [9].

Для подготовки таких кадров Минсельхоз и МГИМО инициировали создание кафедры «Международные аграрные рынки и внешнеэкономическая деятельность в АПК». Как ожидается, ее выпускники будут востребованы и в системе органов государственной власти, и в бизнес-сообществе. Данный вуз является не только кузницей дипломатических кадров, но и авторитетным международным аналитическим центром. По итогам заседания Минсельхоз России и МГИМО подписали соглашение о сотрудничестве, целью которого является создание и развитие такой кафедры [10].

Сегодня особую актуальность приобретает изучение «прорывных» методов внедрения инновационных технологий и проектов в аграрный сектор народного хозяйства. В условиях пролонгации санкций США и стран Евросоюза в отношении России внедрение прогрессивных технологий и проектов в АПК должно благотворно отразиться на развитии экспортоориентированной аграрной экономики страны.

По данным Организации экономического сотрудничества и развития (ОЭСР), производительность труда в России в два раза ниже, чем в ведущих странах мира, входящих в ОЭСР. Так, например, результаты среднестатистического российского работника эксперты ОЭСР оценили в 26,5 долл. в 1 ч. Данный показатель был получен путем деления валового внутреннего продукта (ВВП), созданного в 2017 г., на число людей, занятых в экономике за тот же период. Из 36 стран, охваченных исследованием, ниже показатель был засвидетельствован только в Мексике - 21,6 долл. в 1 ч. В Ирландии работники за 1 ч производят товаров почти на 100 долл. [10, с. 4]. 
Анализ индекса производительности труда по России и основным отраслям экономики РФ (по разделам ОКВЭД) в 2003-2014 гг. [12] (рис. 3) свидетельствует о том, что в период 2003-2009 гг. производительность труда в сельском хозяйстве изменялась практически такими же темпами, как и по другим основным отраслям экономики (за исключением 2008 г.). В 2009 г. производительность труда имела отрицательную динамику по отношению к предыдущему году, но такая тенденция была характерна для всех отраслей экономики, за исключением добычи полезных ископаемых. В период 20112014 гг. наблюдается некоторая волатильность в производительности труда в сельском хозяйстве.

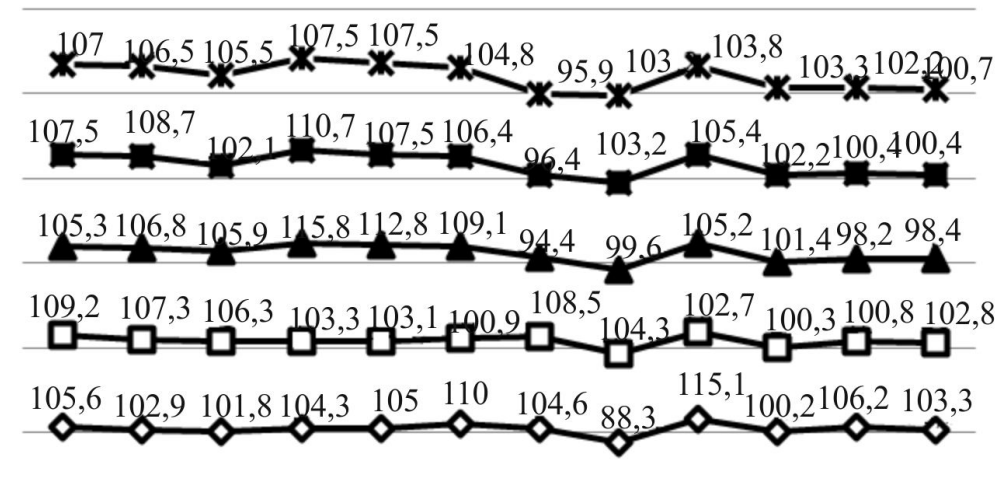

200320042005200620072008200920102011201220132014

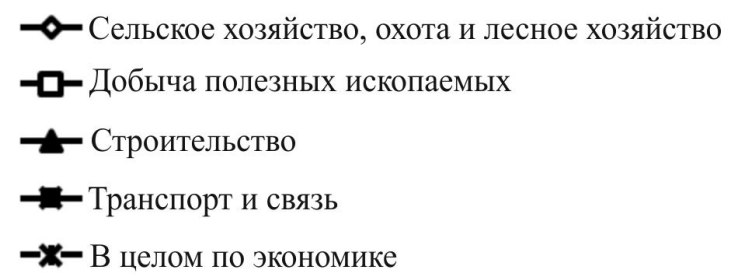

Рис. 3. Индекс производительности труда по России и основным отраслям экономики РФ (по разделам ОКВЭД) в 2003-2014 гг.

(в \% к предыдущему году) [11]

Но сами по себе эти цифры вторичны. Производительность труда стабильно растет, когда ВВП страны увеличивается на основе роста конкурентоспособности экономики. Низкие результаты России в рейтинге ОЭСР говорят о том, что большинство российских компаний проигрывает своим зарубежным конкурентам. Зададимся вопросом: «Чего им не хватает, чтобы стать эффективнее?». Нужны новые прорывные технологии, позволяющие выпускать продукцию с меньшими затратами. Но с их разработкой и внедрением 
много проблем. Ученые нередко уезжают из России за рубеж, где возможностей для внедрения их идей больше. В самой России высококвалифицированных специалистов, владеющих новыми технологиями, особенно цифровыми, не хватает. И промышленные предприятия неохотно идут на замену старых методов новыми, позволяющими выполнять работу в 3-5 раз быстрее. Ведь, с одной стороны, это приведет к потере работы для тысяч людей, а с другой стороны, финансовых ресурсов не хватает ни для приобретения нового оборудования, ни тем более для переподготовки сокращенных кадров.

К тому же сегодня в России 70 \% ВВП создается в государственном секторе экономики. И в борьбе за госзаказы часто важнее оказывается не технологическая «продвинутость», а связи. В тендерах побеждают одни и те же компании. И если нет уверенности, что сумеешь их обойти, опасно рисковать, делая крупные инвестиции в новую технику и цифровые системы [13, с. 4].

Исходя из вышеизложенного, на наш взгляд, низкие результаты производительности труда в России можно объединить в 5 наиболее важных и, следовательно, требующих безотлагательного решения корреляционных (взаимосвязанных) причин (проблем):

1. Социально-экономический фактор является основополагающим. «Уровень безработицы в сельских территориях достигает $8 \%$, тогда как в городе этот показатель составляет 4,3\%. Доля сельского населения с денежными доходами ниже прожиточного минимума - 20 \%. В городе $-11,2$ \%. Более $67 \%$ жилищного фонда в сельской местности оборудовано не всеми видами благоустройства, в городе - менее $21 \% 400$ тысяч сельских школьников вынуждены обучаться в две и даже три смены. Нормативным требованиям отвечают только $53 \%$ местных и немногим более $43 \%$ региональных дорог. Менее 63 \% сельских домохозяйств имеют персональный компьютер, тогда как в городе показатель - 78,3 \%. И чуть более половины домохозяйств имеют скоростной доступ в интернет, в городе - порядка 80 \%. Сельское население за 10 лет сократилось на 500 тысяч человек»[14]. «Заработная плата в сельском хозяйстве составляет всего 57 \% от средней по экономике, тогда как в 1990 г. она была практически на среднероссийском уровне - 95,5 \%. Таким образом, сельские труженики вносят значительный финансовый вклад в воспроизводство отрасли ценой собственного недопотребления» [15, с. 7].

Решению вышеуказанных социальных проблем на селе сможет помочь госпрограмма комплексного развития сельских территорий. В рамках госпрограммы предполагается решение следующих ключевых задач: строительство жилья и развитие инженерной инфраструктуры, в первую очередь коммунальной; доступность и качество медицинских услуг и образования; развитие и повышение качества транспортно-логистической инфраструктуры и общественного транспорта; физическая доступность продуктов питания и бытовых товаров; покрытие территории современными средствами связи; возможность 
физического развития населения; доступ к системе предоставления социальных услуг; развитие рекреационной системы, экотуризма; улучшение экологической ситуации [16].

12 марта 2019 г. был опубликован Проект государственной программы комплексного развития сельских территорий. Разработчиком выступил Минсельхоз РФ. Реализовывать программу Министерство планирует с 2020 по 2025 г. Всего на нее будет выделено 1,38 трлн руб., из них 1,06 трлн руб. - из федерального бюджета. Основной целью программы является комплексное развитие села. Для этого в пятилетний срок планируется сократить разрыв между селом и городом. Так, сейчас средняя сельская семья в месяц может потратить примерно на треть меньше, чем средняя городская. К концу госпрограммы сельская семья должна быть беднее всего на четверть. Самым приятным бонусом для жителей села и тех, кто планировал туда переехать, станет льготная ипотека по ставке не выше 1 \% годовых: такая мера предусмотрена в проекте программы. К 2025 г. площадь жилья для селян составит более 5,5 млн м². Всего к участию в программе планируется привлечь 14500 населенных пунктов и создать 2,5 млн рабочих мест. Ключевым механизмом госпрограммы станет конкурс региональных проектов, которые будут софинансироваться государством. На сегодняшний день проект находится только на стадии обсуждения и из почти 1,5 трлн руб. распределены только 200 млрд руб. [17].

2. Большинству российских промышленных и сельскохозяйственных предприятий необходимы новые «прорывные» технологии, позволяющие выпускать продукцию с меньшими затратами и притом экологически чистую. Главным вектором развития такой политики должно явиться обеспечение национальной продовольственной безопасности страны, поэтому производство и продвижение органических продуктов в России будет сопровождаться поддержкой на правительственном уровне.

3. С другой стороны, внедрение в практику действующих «по старинке» предприятий инновационных методов и технологий, позволяющих производить в 3-5 раз быстрее качественную продукцию, приведет к потере работы для тысяч специалистов. По данным Росстата, уже сегодня безработица в сельской местности составляет $8 \%$ (для сравнения в городе $-4,3 \%$ ). А по данным экспертов ВНИИ экономики сельского хозяйства, уровень безработицы уже достиг 14 \%. Это более 2 млн чел., а на бирже труда зарегистрировано всего 306 тыс. чел. Данная проблема усугубляется низкими показателями рождаемости в сельской местности, которая снижается темпами, превышающими показатели городской местности. Так, например, за период 19952017 гг. естественная убыль сельского населения и миграционный отток составили в совокупности 2,5 млн чел. По прогнозам Росстата, в дальнейшем этот процесс ускорится, и к 2036 г. численность сельского населения сократится еще на 4,6 млн чел., т.е. до 33 млн чел. Пагубную роль в этом процессе 
сыграла политика оптимизации, что привело к закрытию малокомплектных сельских школ, больниц, ФАПов, детсадов, клубов и т.д.

В разрешении обеих проблем может помочь только грамотная финансово-кредитная политика государства, направленная на оказание инвестиционной поддержки в рамках бюджетных ассигнований по целевым статьям (государственным программам Российской Федерации) [17, с. 98]. Ведь вся цепочка, от НИОКР до внедрения нового оборудования, технологий в производственный процесс, нуждается в финансировании ровно так же, как и процесс переподготовки сокращенных кадров.

4. Немаловажной проблемой в решении вопроса повышения производительности труда является коррупционная составляющая. На сегодняшний день, в России 70 \% ВВП создается в государственном секторе экономики. И в борьбе за госзаказы, к сожалению, важнее оказывается не инновационная направленность проекта, а злоупотребление служебным положением и другие нелегитимные частнособственнические интересы. Как следствие, в тендерах побеждают одни и те же компании. Тем не менее стоит отметить высокий уровень производительности труда в компаниях, выполняющих проекты под патронажем Правительства РФ и лично Президента.

5. При проведении анализа корреляционных проблем производительности труда и их влияния на развитие АПК важным является изучение регионального ракурса проблемы. Так, например, в сельском хозяйстве Республики Дагестан в 2017-2018 гг. наблюдались парадоксальные случаи производительности труда. Если в 2017 г. Дагестан занимал первое место среди других регионов страны по численности крупного рогатого скота (1,118 млн голов), в том числе коров [18, с. 90], то в 2018 г. данные показатели значительно снизились: до 976,8 тыс. голов, в том числе коров до 477 тыс. голов. По данным министерства сельского хозяйства и продовольствия РД, также снижение наблюдалось по числу овец и коз - до 4,3 млн голов, птицы - более чем на миллион голов. Но, тем не менее, на таком фоне сокращения численности поголовья КРС наблюдается стабильное увеличение производства продукции животноводства в сельхозпредприятиях, КФХ и ЛПХ. Так, по информации Дагестанского комитета по статистике, объем производства продукции сельского хозяйства всех видов товаропроизводителей в январе-июле 2018 г. оценивается в 34,2 млрд руб. (101,2 \% к соответствующему периоду 2017 г.) $[19$, c. 7]. Данные показатели вызывают сомнение еще и потому, что «по итогам Всероссийской сельскохозяйственной переписи 2016 г. были скорректированы в сторону уменьшения объемы производства в хозяйствах населения, в связи с чем, по предварительной оценке Росстата, в 2018 г. роста производства продукции сельского хозяйства не ожидается. В целом по агропромышленному комплексу в прошлом году рост составил 2,3 \%» [20]. 
При комплексном изучении корреляционных проблем производительности труда в аграрной сфере и применении инвестиционных, финансовокредитных методов, инновационных технологий и проектов в сфере агропромышленного производства Россия может рассчитывать на эффективное решение проблем продовольственной независимости, безопасности и «прорывной» экспортоориентированный путь развития.

\section{Список литературы}

1. Россия в цифрах. 2018: крат. стат.сб./Росстат. - М., 2018 - 522 с.

2. Аграрная политика современной России: научно-методические аспекты и стратегия реализации: моногр. / С.Г. Сальников, В.А. Сарайкин, О.С. Соболев, Е.А. Соскиева. - М.: Никоновские чтения, 2015. - 518 с.

3. Дмитрий Патрушев провел совещание с руководством Минсельхоза об итогах работы в 2018 году и планах на 2019 год // Сайт М-ва сел. хоз. РФ. URL: $\quad$ http://mcx.ru/press-service/news/dmitriy-patrushev-provel-soveshchanie-srukovodstvom-minselkhoza-ob-itogakh-raboty-v-2018-godu-i-pla/ (дата обращения: 10.01.2019).

4. Дмитрий Патрушев: государство субсидирует порядка 16 тыс. инвестпроектов в АПК // Сайт М-ва сел. хоз. РФ. - URL: http://mcx.ru/pressservice/news/dmitriy-patrushev-gosudarstvo-subsidiruet-poryadka-16-tys-investproektov-v-apk/ (дата обращения: 08.01.2019).

5. До 2024 года на поддержку экспорта АПК будет направлено свыше 406 млрд руб. // Сайт М-ва сел. хоз. РФ. - URL: http://mcx.ru/press-service/ news/do-2024-goda-na-podderzhku-eksporta-apk-budet-napravleno-svyshe-406-mlrdrubley/ (дата обращения: 10.01.2019).

6. Годовой отчет открытого акционерного общества «Дербентский завод игристых вин» (ОАО «ДЗИВ») за 2014 год [Электронный ресурс]. - URL: https://megaobuchalka.ru/4/10848.htmlc (дата обращения: 17.01.2019).

7. Отчетные данные ОАО «Дербентский завод игристых вин» за 2016 год [Электронный ресурс]. - URL: https://yandex.ru/clck/jsredir?bu=uniq15165301719 $562604413 \&$ from=yandex.ru\%3Bsearch\%2F\%3Bweb\%3B\%3B\&text=\&etext=1673. pz (дата обращения: 17.01.2019).

8. «Это был бы проект, сравнимый с освоением целины». Евгений Савченко предложил новый нацпроект // Сайт Союза органического земледелия. URL: https://soz.bio/evgenij-savchenkopredlozhilnovyjnacproekt/?fbclid=IwAR14 owDxAJDFGa6KQPK51NYvTUEqrPAx1n-xyFbuY_F2ALLTvVm1cNWL13M (дата обращения: 21.01.2019).

9. Васильева И.В., Арефьев В.Н., Можаев Е.Е. Трансферт современных технологий в аграрное производство малых форм хозяйствования как путь 
активизации инновационных процессов в отрасли // Вестник Алтайской академии экономики и права. - 2018. - № 2. - С. 30-37.

10. Создание сети атташе по АПК поможет позволить России войти в десятку крупнейших сельхозэкспортеров в мире // Сайт М-ва сел. хоз. РФ. URL: http://mcx.ru/press-service/news/sozdanie-seti-attashe-po-apk-mozhet-pozvolit-rossii-voyti-v-desyatku-krupneyshikh-selkhozeksporterov/ (дата обращения: 08.01.2019).

11. Морыженков В. Почему в России низкая производительность труда? // Аргументы и факты. - 2019. - № 7. - С. 4.

12. Малых Н.И. Социально-экономическая статистика: моногр.: в 2 т. М.: Юрайт, 2016. - Т. 2.

13. Данные Федеральной службой государственной статистики [Электронный pecypc]. - URL: http://www.gks.ru/wps/wcm/connect/rosstat_main/ rosstat/ru/statistics/efficiency/\# (дата обращения: 03.04.2019).

14. Доклад Дмитрия Патрушева на совещании о ходе подготовки государственной программы комплексного развития сельских территорий // Сайт Правительства РФ. - URL: http:/government.ru/news/35538/ (дата обращения: 16.02.2019).

15. Голод Г. Село станет более привлекательным: Минсельхоз разработал очередную программу развития сельских территорий [Электронный ресурс] // Профессиональная сеть фермеров и людей агробизнеса. - URL: https://agrobook.ru/blog/user/gleb-golod/selo-stanet-bolee-privlekatelnym (дата обращения: 01.04.2019).

16. Постановление Правительства Пензенской области от 20.10.2008 № 674-пП [Электронный ресурс] // Сейчас.py. - URL: http://pnzreg.ru/upload/ iblock/c77/c7717bb5b016feac7baff146a2a7d158.pdf

17. Ушачев И. Эх ты! Деревня! // Аргументы и факты. - 2019. - № 8. - С. 7.

18. Алиева 3.Б. Концептуальные основы метода компаративного анализа государственной поддержки АПК России // Друкеровский вестник. 2018. - № 1(21). - С. 85-106.

19. Магомедова А. Куда уходит поголовье? // Аргументы и факты. 2019. - № 7. - С. 7.

20. Рост АПК по итогам 2018 года составил 2,3\% // Агровестник. 2019. - 11 февр.

\section{References}

1. Rossiia v tsifrakh. 2018 [Russia in numbers]. Kratkii statisticheskii sbornik, Rosstat. Moscow, 2018, 522 p, available at: http://www.gks.ru/wps/wcm/ connect/rosstat_main/rosstat/ru/statistics/publications/catalog/doc_1135075100641 (accessed 08 January 2019). 
2. Sal'nikov S.G., Saraikin V.A., Sobolev O.S., Soskieva E.A. Agrarnaia politika sovremennoi Rossii: nauchno-metodicheskie aspekty i strategiia realizatsii [Agricultural policy of contemprorary Russia: Scientific and methodological aspects and strategies of implementation]. Moscow, Nikonovskie chteniia, 2015, 518 p., available at: http://www.viapi.ru/download/2015/20160919-Nik-2015.pdf (accessed 08 April 2019).

3. Dmitrii Patrushev provel soveshchanie s rukovodstvom Minsel'khoza ob itogakh raboty v 2018 godu i planakh na 2019 god [Dmitry Patrushev held the meeting with Ministry of Agriculture management on the results of 2018 and plans for 2019]. Sait Ministerstva sel'skogo khoziaistva RF, available at: http://mcx.ru/ press-service/news/dmitriy-patrushev-provel-soveshchanie-s-rukovodstvom-minselkhoza-ob-itogakh-raboty-v-2018-godu-i-pla/ (accessed 10 January 2019).

4. Dmitrii Patrushev: gosudarstvo subsidiruet poriadka 16 tys. investproektov v APK [Dmitry Patrushev: The State subsidizes about 16 thousand investment projects in the agro-industrial complex]. Sait Ministerstva sel'skogo khoziaistva RF, available at: http://mcx.ru/press-service/news/dmitriy-patrushev-gosudarstvo-subsidiruet-poryadka-16-tys-investproektov-v-apk/ (accessed 08 Januray 2019).

5. Do 2024 goda na podderzhku eksporta APK budet napravleno svyshe 406 mlrd. rublei [More than 406 billion rubles will be allocated to export support of agroindustrial complex until 2024]. Sait Ministerstva sel'skogo khoziaistva $R F$, available at: http://mcx.ru/press-service/news/do-2024-goda-na-podderzhku-eksporta-apk-budetnapravleno-svyshe-406-mlrd-rubley/ (accessed 10 January 2019).

6. Godovoi otchet otkrytogo aktsionernogo obshchestva "Derbentskii zavod igristykh vin" (OAO "DZIV") za 2014 god [Annual report of the open joint-stock company "Derbent plant of sparkling wines" (OAO "DZIV") for 2014]. Available at: https://megaobuchalka.ru/4/10848.htmlc (accessed 17 January 2019).

7. Otchetnye dannye OAO "Derbentskii zavod igristykh vin" za 2016 god [Reporting data of OAO "Derbent plant of sparkling wines" for 2016]. Available at: https://yandex.ru/clck/jsredir?bu=uniq15165301719562604413\&from=yandex.ru\%3B search\%2F\%3Bweb\%3B\%3B\&text=\&etext=1673.pz (accessed 17 January 2019).

8. "Eto byl by proekt, sravnimyi s osvoeniem tseliny". Evgenii Savchenko predlozhil novyi natsproekt ["It would be a project comparable to the development of virgin land". Evgeny Savchenko proposed a new national project]. Sait Soiuza organicheskogo zemledeliia, available at:https://soz.bio/evgenijsavchenkopredlozhilnovyjnacproekt/?fbclid=IwAR14owDxAJDFGa6KQPK5INYv TUEqrPAx1n-xyFbuY_F2ALLTvVm1cNWL13M (accessed 21 January 2019).

9. Vasil'eva I.V., Aref'ev V.N., Mozhaev E.E. Transfert sovremennykh tekhnologii $\mathrm{v}$ agrarnoe proizvodstvo malykh form khoziaistvovaniia kak put' aktivizatsii innovatsionnykh protsessov $\mathrm{v}$ otrasli [Transfer of modern technologies to agricultural production of small forms of economy management as a way of activating innovative processes in the industry]. Vestnik Altaiskoi akademii ekonomiki 
i prava, 2018, no. 2 , pp. $30-37$, available at: $\mathrm{http}$ ://vaael.ru/ru/article/view? $\mathrm{id}=29$ (accessed 06 January 2019).

10. Sozdanie seti attashe po APK pomozhet pozvolit' Rossii voiti v desiatku krupneishikh sel'khozeksporterov v mire [Creating a network of AIC attachés will make Russia one of the world top ten agricultural exporters in the world]. Sait Ministerstva sel'skogo khoziaistva $R F$, available at: http://mcx.ru/pressservice/news/sozdanie-seti-attashe-po-apk-mozhet-pozvolit-rossii-voyti-vdesyatku-krupneyshikh-selkhozeksporterov/ (accessed 08 January 2019).

11. Moryzhenkov V. Pochemu v Rossii nizkaia proizvoditel'nost' truda? [Why is there low labour productivity in Russia?]. Argumenty i fakty, 2019, no. 7, p. 4.

12. Malykh N.I. Sotsial'no-ekonomicheskaia statistika [Socio-economic statistics]. Moscow, Iurait, vol. 2, 2016, available at: https://avidreaders.ru/book/ statistika-v-2-t-tom-2.html (accessed 06 January 2019).

13. Dannye Federal'noi sluzhboi gosudarstvennoi statistiki [Data of Federal State Statistics Service]. Available at: http://www.gks.ru/wps/wcm/connect/ rosstat_main/rosstat/ru/statistics/efficiency/\# (accessed 03 April 2019).

14. Doklad Dmitriia Patrusheva na soveshchanii o khode podgotovki gosudarstvennoi programmy kompleksnogo razvitiia sel'skikh territorii [Dmitry Patrushev's report at the meeting on the progress in the state program for the integrated development of rural territories]. Sait Pravitel'stva $R F$, available at: http://government.ru/news/35538/ (accessed 16 February 2019).

15. Golod G. Selo stanet bolee privlekatel'nym: Minsel'khoz razrabotal ocherednuiu programmu razvitiia sel'skikh territorii [The village will become more attractive: The Ministry of Agriculture has developed another program for the development of rural areas]. Professional'naia set' fermerov i liudei agrobiznesa, available at: https://agrobook.ru/blog/user/gleb-golod/selo-stanet-bolee-privlekatelnym (accessed 01 April 2019).

16. Postanovlenie Pravitel'stva Penzenskoi oblasti ot 20.10.2008 № 674-pP [Decree of the government of Penza Region of Oct. 20, 2008 no. 674-pP]. Seichas.ru, available at: http://pnzreg.ru/upload/iblock/c77/c7717bb5b016feac 7baff146a2a7d158.pdf.

17. Ushachev I. Ekh ty! Derevnia! [Oh, you! Village!]. Argumenty i fakty, 2019 , no. 8 , p. 7.

18. Alieva Z.B. Kontseptual'nye osnovy metoda komparativnogo analiza gosudarstvennoi podderzhki APK Rossii [The conceptual basis of the method of comparative analysis of state support for AIC of Russia]. Drukerovskii vestnik, 2018, no. 1(21), pp. 85-106.

19. Magomedova A. Kuda ukhodit pogolov'e? [Where does the livestock go?]. Argumenty i fakty, 2019, no. 7, p. 7. 
20. Rost APK po itogam 2018 goda sostavil 2,3\% [The growth of AIC in 2018 amounted to 2.3\%]. Agrovestnik, Feb. 11, 2019, available at: https://agrovesti.net/news/indst/rost-apk-po-itogam-2018-goda-sostavil-2-3.html (accessed 19 February 2019).

Оригинальность $92 \%$

Получено 15.04.2019 Принято 17.05.2019 Опубликовано 04.10.2019

\author{
Z.B. Aliyeva
}

\title{
PROBLEMS AND TRENDS OF THE STATE AGRARIAN POLICY IN THE LIGHT OF THE FEDERAL PROJECT «EXPORT OF AGRICULTURAL PRODUCTS»
}

The work analyzes the influence of financial and credit tools on foreign economic activity in terms of Russian export and import of food products and agricultural raw materials in 2000-2017. Covered are the main avenues of the Federal project «Export of Agricultural Products», including the comprehensive program of the international competitiveness (CPIC), the issues of implementing innovative technologies in production of organic products, operation of laylands in Russia. For the purpose of determination of optimum volumes of preferential crediting, increase in labor productivity, full load of the available production capacities and, as a result, increase in profitability of the plant, calculation of the greatest possible production of wine materials, natural and sparkling wines on JSC Derbent Plant of Sparkling Wines (DPSW) is made. In calculations economic-mathematical methods in the form of the linear equations were used. Based on the data of the Organization for Economic Cooperation and Development (OECD), the author investigates the correlation problems related to low results of labor productivity in Russia and hindering the process of breakthrough development of agrarian and industrial complex. As a result, five main reasons for labour productivity decline in the industry are designated. For the purpose of identifying criteria of potential productivity increase, a comparative analysis is carried out of the index of labour productivity in agriculture and primary branches of the Russian economy in 2003-2014 (in \% compared to the previous year). In the conditions of prolongation of American and European sanctions against Russia, the ongoing policy of import substitution, an emphasis is placed on looking at breakthrough methods of implementing innovative technologies and projects in the agrarian sector of the national economy.

Keywords: import and export of food products and agricultural raw materials, biologization, labour productivity, innovative technologies, state regulation of agrarian and industrial complex, soft loan.

Zarema B. Aliyeva - Candidate of Economic Sciences, Associate Professor, Department of Finance and Credit, Dagestan State University of National Economy, e-mail: aliza69@mail.ru.

$$
\text { Received 15.04.2019 Accepted 17.05.2019 Published 04.10.2019 }
$$

